\title{
Sobre El Catecismo político burlesco de los coyotes del Payo del Rosario (1827)*
}

\author{
Mariano Franco Figueroa** \\ Universidad de Cádiz, España
}

\begin{abstract}
RESUMEN
Analizamos el Catecismo de Pablo de Villavicencio, el Payo del Rosario, y su adaptación estructural al texto catequético tradicional de Ripalda para la propaganda de los conceptos liberales y la defensa de un nuevo sistema político en la recién independiente nación mexicana. El estudio permite afirmar que se trata de un panfleto más en su haber político, que se sirve de metáforas y comparaciones continuadas para construir una imagen cercana y fácilmente interpretable por el pueblo con la que propagar la ideología liberal e insurgente. Además de la constatación de un estilo discursivo burlesco y sarcástico, con una finalidad menos informativa y más de opinión, observamos la acomodación léxica a los nuevos contextos históricos y la consustancial variación lingüística textual, con muestras preferenciales de usos lingüísticos de su autor, que revelan rasgos dialectales y regionales contrastivos, especialmente visibles en el vocabulario diferencial.
\end{abstract}

Palabras clave: español de América, léxico ilustrado, variedad de registros.

* Del proyecto FFI2011-24806/FILO, MICINN.

** Para correspondencia, dirigirse a: Mariano Franco Figueroa (mariano.franco@uca.es), Departamento de Filología, Facultad de Filosofía y Letras, Universidad de Cádiz, Avda. Gómez Ulla, 1, 11003 Cádiz, España. 
On the El Catecismo político buRlesco de los Coyotes by Payo DEL Rosario (1827)

\begin{abstract}
We analyze the Catecismo by Pablo de Villavicencio, el Payo del Rosario, and his structural adjustment to the catechist text traditionally of Ripalda for the propaganda of the liberal concepts and the defense of a new political system in the newly independent Mexican nation. The study shows that this text is another one among his political pamphlets, in which he uses repetitive metaphors and comparisons to construct a close and easily interpretable image to spread the liberal and insurgent ideology among the people. Besides the verification of a burlesque and sarcastic discursive style, with a less informative and more opinionated purpose, we observe the author's lexical accommodation to the new historical contexts and the consubstantial linguistic textual variation, with preferential samples of linguistic uses, which reveal contrastive dialectal and regional features, visible in the differential vocabulary specially.
\end{abstract}

Key words: Spanish of America, Enlightenment vocabulary, variety of registers.

Recibido: 02/05/13 Aceptado: 30/05/13

\title{
PANFLETISMO CARICATURESCO Y SERMONARIO BURLESCO
}

La tradicional vía propagandística de la opinión política encarnada en periódicos, carteles y hojas sueltas, utilizada desde finales del siglo XVIII y destacada en la sociedad hispana como soporte de su crítica antinapoleónica, se ve favorecida con la proclamación de la independencia colonial americana y con la asunción de la aireada ley de la libertad de expresión. Su defensa justifica los crispados debates políticos y los enfrentamientos furibundos entre los partidarios de una $\mathrm{u}$ otra posición ideológica, tanto como grupo social o como individuo irreconciliable con su adversario. La primera década postindependentista novohispana fue terreno abonado para la proliferación de las publicaciones políticas; prensa, panfletos, carteles, catecismos, y toda clase de documentos circulan en una sociedad dividida entre la esperanza de una justicia más igualitaria, de un futuro más liberal e ilustrado para el 
pueblo, y la permanencia en una supuesta seguridad del antiguo régimen monárquico, conservador que aprovecha el sentimiento religioso católico extendido en la población.

La ausencia de una censura institucional, acorde con el ambiente político más constitucionalista e insurgente, permite la proliferación de publicaciones que plasman abiertamente las diferentes corrientes de opinión y el diálogo violento entre sus defensores y detractores. A través de la prensa, los distintos focos de debate político se utilizan como mecanismos de polarización ideológica capaces de atraer y conformar grupos sociales adictos a cada discurso político establecido ${ }^{1}$. Sin embargo, la función de esta prensa doctrinaria chocaba con los inconvenientes propios de un medio de comunicación de masas establecido, regularizado e incluso constreñido en sus expresiones lingüísticas por razón del grupo social al que ideológicamente representa y sirve. La necesidad no solo de difundir las ideas sino de persuadir a la población, mayoritariamente analfabeta y, por tanto, ajena a la lectura de periódicos, propicia el surgimiento de los panfletos ${ }^{2}$, escritos políticos de carácter discontinuo y en su mayoría de distribución clandestina, ajenos a las limitaciones de una escritura ortodoxa y plagados de expresiones satíricas y socialmente escandalosas como forma de denuncia frente al poder institucional establecido. Las expresiones extravagantes, caricaturescas y sarcásticas con que se adula o se difama al oponente político se amparan en la reconocida libertad de imprenta, reafirmada por las Cortes gaditanas. En el lenguaje panfletario, accesible para el pueblo y marginado de los medios periodísticos institucionalizados, no se descartan el uso de voces soeces y grotescas, de mecanismos irónicos y burlescos, en gran medida colmados

\footnotetext{
Rojas (2003) describe ampliamente esta guerra de pluma y los enfrentamientos continuados de algunos periódicos, como El Águila Mejicana o El Sol, difusores propagandistas de la ideas liberales o conservadoras, achacadas a la masonería yorkina o escocesa, republicanas o monárquicas, iturbidistas o borbonistas, federales o unitarias, respectivamente.

2 Sobre la forma y estructura del panfleto, véase Coloma Lleal (1982). Del acercamiento de la sociedad a las actividades políticas y de la consiguiente motivación de la opinión pública en los asuntos antes conferidos a los sectores más privilegiados responde la figura del panfletista, personaje funcional destacado en la primera década postindependentista y responsable, entre 1821 y 1829 , de la escritura y difusión de unos mil panfletos (Rojas 1997: 42). Con escasas excepciones, como las de Fernández de Lizardi o Francisco Ibar, la mayoría de los autores de panfletos estaban marcados por su origen social bajo y su carencia de preparación intelectual, lo que les separaba del grupo de poder político y de los sectores más cultos de la sociedad, que los veían como radicales, ignorantes y volubles, al tiempo que recibían la crítica y la admiración de los estratos más bajos, bien por su falta de espíritu combativo bien por su radical anticlericalismo. A pesar de esta situación de marginalidad social, su actitud de denuncia ante los mecanismos de control político y su poder de sociabilizar la distinta propaganda ideológica, sirven de puente entre ambos estratos (Bonilla 2007: 128).
} 
por los contrasentidos jergales de las mismas palabras, para conseguir la eficacia de su discurso político. Es en esta actividad panfletaria donde destaca nuestro autor, Pablo de Villavicencio, conocido por su seudónimo el Payo del Rosario, en alusión a este personaje del pueblo con el que se identifica tanto por su origen como por su coexistencia social entre las clases más bajas y desfavorecidas. Comparte y denuncia las injusticias que las desolan y se vale de su conocimiento más cercano del estilo coloquial y más popular de su habla para divulgar, desde dentro, las consignas políticas que defiende.

La marginalidad del panfletista, falto de reconocimiento social y carente de una formación intelectual que lo avalara, no es óbice para que los numerosos escritos sueltos y salpicados de imágenes ${ }^{3}$ de los que responde el Payo del Rosario llegaran a todos, a gentes analfabetas y a un público más letrado. La eficacia de sus escritos se colige de la popularidad que alcanzan y de su consiguiente persecución y denuncia institucional ${ }^{4}$. No cabe duda de su constante militancia insurgente y de la tenacidad con la que la aireaba, con continuos enfrentamientos y sus consecuentes encarcelamientos ${ }^{5}$.

Valedor de la opinión pública en los asuntos de la política, aplica sus habilidades periodísticas en estas manifestaciones panfletarias como mejor

3 Las caricaturas y pinturas alegóricas usadas en la defensa de la causa independentista continúa, ahora en los años veinte, el imaginario simbólico rebelde de los primeros tiempos y sirve de soporte crítico también a nuestro autor, que recurre, como vocero de las actitudes políticas y sociales censurables, a dibujos alusivos a personajes fácilmente reconocidos por el pueblo (véase Bonilla 2007).

4 Del reconocimiento de esta labor panfletaria, iniciada a su llegada a la ciudad de México, en 1822, y ampliamente difundida en todos los sectores sociales y políticos novohispanos, da cuenta la propia exigencia de que no se reeditaran sin su permiso (Pani 2003: 367) y la constatación de que ocupa un primer lugar entre los autores más prolíficos y al mismo tiempo más denunciados ante los jurados de imprenta, con reiteradas penas de prisión que no logran socavar su espíritu liberal y combativo (Olea 1987). Baste recordar que sus papeles $O$ se destierra el coyote o mata a nuestras gallinas (1824), De coyote a perro inglés, voy al coyote ocho a tres, Si no se van los ingleses hemos de ser sus esclavos (1825), fueron enjuiciados por subversivos apenas promulgada la Constitución de 1824.

5 Desde su enconado enfrentamiento con el poder civil y eclesiástico ejercido en su patria natal, que lo llevó incluso a alistarse en las tropas insurgentes ya en 1811, su injerencia en la vida pública no cesa. En sus publicaciones confirmamos su comprometida participación, así en el Plan de Iguala, con críticas y apoyos más tardíos a Agustín de Iturbide, en la defensa enconada de la logia yorkina frente a la escocesa, o en el Motín de la Acordada, por citar algunas de las más relevantes. Su arrostrado espíritu le granjea la persecución de los distintos representantes del ejecutivo en este periodo postindependentista, como los presidentes Guadalupe Victoria, Vicente Guerrero o Anastasio Bustamante, que lo consideran un enemigo jurado del gobierno establecido. 
forma de presión al poder ${ }^{6}$. Su identidad social le permite conocer los mecanismos más eficaces para atraer a los sectores populares con recursos recurrentes, y en su mayoría extremistas, hacia determinada tendencia política. No obstante, si el género satírico de sus libelos se revela como procedimiento más eficaz para la propaganda política, la idiosincrasia de esta sociedad novohispana, persuadida por valores religiosos más tradicionales, lo conduce a la adopción de los habituales catecismos como forma privilegiada en su estrategia revolucionaria ${ }^{7}$. A la persuasión motivada por la difusión de las ideas a través de imágenes y discursos panfletarios, más propios de una escritura anónima, se une este probado medio catequético que aúna su reiterado código religioso con el político. El lenguaje doctrinal cristiano consiente igualmente la connotación política a través de la burla y del sarcasmo y actúa de soporte emotivo de la ideología política que pretende mover la conciencia social ${ }^{8}$.

${ }^{6} \quad$ No obtuvo el reconocimiento público y sí que contó con muchos detractores y enemigos en la profesión. Sirva de ejemplo el texto que anuncia su deceso, escrito por Bustamante: "escritor público contra la expresa voluntad de Dios y de la patria, eco de la anarquía, sansculote desaforado e imprudente, enano de don Lorenzo Zavala con quien se divertía y a quien protegía, no por compasión, sino como instrumento de sus ideas, no de otro modo que un cazador mantiene a un perro galgo para que le pesque las liebres. Nacido en la Villa del Rosario abrazó el oficio de sastre, y siempre lo fue rinconero y remendón; no bastándole lo que ganaba para vivir, era el juglar del pueblo, y hacía unas veces de bato y otras de Diablo en los coloquios; vino a México, y se metió a escritor con las mismas disposiciones que fray Gerundio a predicador" (Bonilla 2007: 130).

7 La efectividad del método catequista en la evangelización americana, con preguntas y respuestas que divulgaban los contenidos religiosos, convence a los políticos, conservadores o ilustrados, que ven en los catecismos el medio más idóneo para la difusión de su ideología. Su proliferación confirma la importancia como instrumento político en los nuevos contextos sociolingüísticos, especialmente rurales, que exigen argumentos y explicaciones de los recientes proyectos revolucionarios independentistas, de la lealtad monárquica, de los derechos y deberes de los individuos, esto es, de las ideas de la modernidad ilustrada en las que se pretende implicar al pueblo. La prohibición de muchos de estos catecismos denota igualmente el valor movilizador en España y en América, con circulares enviadas por el gobierno a las provincias españolas $(1814,1819)$ y de ultramar (1816) que censuraban su difusión por sediciosos y destructores del orden establecido. A propósito de referencias bibliográficas sobre los catecismos hispanoamericanos y su interés histórico y social, véanse Ocampo López (1988), Sagredo Baeza (2009).

8 A la instrumentalización política de cartillas y catecismos en el Cádiz de las Cortes atiende Sánchez Hita (2003), con la distinción de tres períodos: de combate, de especulación teórico-pedagógica y de adoctrinamiento constitucional. Considera que se producen, en función de las circunstancias históricas e ideológicas, cambios que afectan incluso a la estructura interna, con un diálogo más fluido en los catecismos en los que predomina un tono más combativo y satírico, y más ralentizado en los destinados a la enseñanza constitucional, de tono más teórico y doctrinal. 
La transgresión ahora se manifiesta en este texto de adoctrinamiento religioso, integrado entre los recursos populares de la denuncia política y moral, sin el forzoso anonimato de libelos y panfletos. Su Catecismo político $^{9}$ se inserta en el contexto satírico y de la caricatura política mexicana, definida por el empleo del lenguaje popular, algunas veces obsceno y escatológico, jergal, pero siempre cercano al público al que se dirige. Aplica a la estructura doctrinal los mecanismos de la amonestación y reprensión de la predicación cristiana y construye un discurso sermonario, reiterativo en la burla radical panfletaria, al servicio de la política. El propio título diluye el laicismo imperante en los ideales revolucionarios ilustrados inserto en el adjetivo político con el calificativo añadido de burlesco $^{10}$; y recoge, además, la labor de instrucción asociada ahora al ámbito político, con el interés ilustrado puesto en la educación de los jóvenes en los nuevos valores de la libertad: "para la instrucción de la juventud". Esta repetida finalidad didáctica, proclamada en catecismos y lecciones acordes con el ideario político de la sociedad ilustrada, queda matizada en la nota de imprenta que cierra el texto y que revela su pretendido sentido burlesco: "Por vna equivocacion se puso en el rubro de este catecismo: para instruccion, lease: para diversion".

9 La obra Catecismo político burlesco de los coyotes. Para la instrucción de la juventud, del Payo del Rosario, seudónimo de Pablo de Villavicencio, México, Imprenta de la calle de Ortega, se ha conservado en la Biblioteca Nacional de México (signatura P-I-5-14) y puede consultarse en la web de esta institución. Asimismo se encuentra digitalizado en su proyecto histórico de los Derechos del Hombre, [en línea] http://www.derechosdelhombre.unam.mx/ libros.htm.

10 Es sabido que el ostensible laicismo de los textos franceses no define los escritos constitucionales españoles y ni americanos, identificados más por su carácter confesional, como se colige en el título IX, De la Instrucción Pública, en su artículo 366, de la Constitución gaditana: "En todos los pueblos de la monarquía se establecerán escuelas de primeras letras, en las que se enseñará á los niños á leer, escribir y contar, y el catecismo de la religión católica, que comprehenderá también una breve exposición de las obligaciones civiles"; y en el capítulo II, De la Religión, artículo 12: "La religión de la Nación española es y será perpetuamente la católica, apostólica, romana, única verdadera. La Nación la protege por leyes sabias y justas, y prohíbe el exercicio de qualquiera otra". 


\section{ANTICLERICALISMO E INSURGENCIA POLÍTICA DEL CATECISMO}

\section{El Catecismo político burlesco de los coyotes. Para instrucción de la juventud del Payo del Rosario responde al mantenimiento de su anticlericalismo} radical de sus primeros tiempos de combate periodístico y panfletario ${ }^{11} \mathrm{y}$ al sentimiento antihispánico posterior, incrementado en una segunda etapa de clara identificación con los principios de la masonería yorquina ${ }^{12}$. No se trata de un catecismo civil y de instrucción ciudadana, sino de un relato de los acontecimientos políticos y sociales que sustituye al mensaje catequético y de un diálogo que argumenta en sus respuestas las bondades de su credo ideológico liberal.

Acorde con la arquitectura de los catecismos políticos de la época independentista, la estructura del texto es una copia literal y manifiesta de la del conocido catecismo Ripalda ${ }^{13}$. Como si de una imagen panfletaria se tratara, describe la verdadera situación del pueblo americano y la denuncia a través de esa estructura catequética. No hay originalidad en el medio empleado, un catecismo más para la enseñanza de las nuevas ideas liberales para el pueblo ${ }^{14}$, pero sí en la forma lingüística que lo manifiesta, un discurso

11 Testimonio de su implacable enfrentamiento con el clero es la crítica a sus ministros, por su complicidad con el sistema monárquico y conservador, inserta en El gallo se halla durmiendo y los coyotes velando, de 1825: "varios que se decian ministros de eterno, aunque solo eran corruptores de su ley, abortaban desde los pulpitos, las mas negras invectivas contra el sistema republicano que justamente hace iguales á los hombres, al paso que encomiaban la tirania de los reyes opresores", "bonzes del despotismo" (f. 4). Ellos propugnan una "Religion de encaje, para el que fuere salbaje" (f. 6). Véase el estudio que sobre su obra realiza su biógrafo Fernández de Córdoba (1961).

12 Una visión general de la masonería en el México independiente de los años veinte, con alusiones al enfrentamiento entre iturbidistas-federalistas y borbonistas-centralistas, en las que participa, como hemos dicho, tanto Lizardi como el Payo del Rosario, puede consultarse en Vázquez Semadeni (2009).

13 Así conocido el Catecismo y exposición breve de la doctrina cristiana, de fray Jerónimo Martínez de Ripalda, publicado en 1618. La importancia del texto radica en que su función va más allá del propio objetivo didáctico de adecuar las bases doctrinales cristianas a la mentalidad de los niños mexicanos y llega a utilizarse como texto básico para el aprendizaje del idioma español en la comunidad indígena, con traducciones en nahua, otomí, tarasco, zapoteca, o maya, por ejemplo.

14 Este formato didáctico, heredado de los franceses, se convierte tanto en España como en América en el vehículo popular para la propagación de las ideas ilustradas y regeneradoras. Así, cabe recordar que en el sistema educativo mexicano se introduce el catecismo civil asociado a la educación cívica, materia obligada en la sociedad novohispana según la Ley de Instrucción, de 1820 (Sotés Elizalde 2009: 203). También en el prólogo de advertencia del Catecismo civil o de instrucción elemental de los derechos, obligaciones y gobiernos en que 
metafórico y satírico que trastoca la investidura religiosa y su condición virtuosa en una denuncia política que delata la falta de verdad y de rectitud en el estamento clerical.

Presenta en su primera parte, págs. 1-24, la exposición de las oraciones litúrgicas, desde el acto de santiguarse, como identificativo de su devoción cristiana, hasta el de contrición o arrepentimiento. En la segunda parte, págs. 25-64, nuestro autor prosigue el calco del popular catecismo, con fidelidad absoluta a sus capítulos referenciados. Con idéntica finalidad, el Catecismo del Payo del Rosario recopila primero los escritos litúrgicos y oraciones que deben aprenderse, con las modificaciones del contenido que el juego burlesco conlleva, y, en el segundo bloque, fijado el dogma, argumenta, con igual estilo dialógico, de pregunta y respuesta, la reinterpretación política de los mismos para la fijación de las ideas partidistas de su nuevo cuerpo doctrinario.

$\mathrm{Su}$ contacto con las primeras publicaciones periódicas insurgentes, como El Despertador Americano ${ }^{15}$, forja su ideario liberal radical e inicia sus dos facetas combativas: anticlericalismo y antihispanismo. El objetivo ideológico de este periódico aprovecha, no obstante, el sentimiento religioso, profundamente arraigado en el espíritu del pueblo, para su causa: “confesad de buena fée la justicia de la Causa Americana, y la necesidad estrecha que Dios y la Patria, la Religion y el Estado, la conciencia y el honor nos impone de tomar las armas" (I, pág. 3). La función del editorial periodístico persigue el levantamiento en armas del pueblo y la desobediencia a las autoridades

debe estar impuesto el hombre libre, formado para la enseñanza pública de las escuelas del Estado de Guanajuato (México, 1827) se justifica el uso de las denominaciones catecismo y civil: "Palabra aceptada moderadamente en los países cultos y católicos de Europa para todo libro escrito en preguntas y respuestas. Se dice civil porque contiene los derechos civiles y obligaciones del ciudadano" (Bustos 1827: 1). No extraña, entonces, que en la reimpresión de la Cartilla ó Catecismo del ciudadano constitucional, que realiza Mariano José de Zúñiga y Ontíveros, en 1820, se prevenga de la reprobación de este formato catequético: "Adviertase que la palabra Catecismo en sentido lato significa el libro donde se explica cualquier doctrina y sus misterios, si los tiene; y asi nadie deberá admirarse ni extrañarse de que al presente se le titule Catecismo del ciudadano constitucional; como asimismo que el haber seguido en algo la fórmula de nuestro Catecismo de doctrina cristiana, no ha habido otro objeto que el de hacer más perceptibles a todos las máximas políticas y constitucionales que se quieren enseñar, estando muy distante el autor de ofender ni de pensamiento nuestra santa Religión y doctrina, que ama, cree y confiesa como católico cristiano".

15 Combativo contra los gachupines, españoles que defienden al rey y a la religión, protectora y garante del régimen monárquico conservador, este periódico, en su primer número de 20 de diciembre de 1810, los había denunciado como "Reos de Alta Traycion", que "habeis estado repitiendo incesantemente á la faz del Mundo entero los juramentos mas solemnes de vencer, ò morir por la Religion, y por Fernando" (I, pág. 1). 
impuestas por la metrópolis, pero, ante el mensaje de acatamiento, difundido constantemente por la institución eclesiástica, subordinada al poder establecido, buscará la forma en la que la creencia más íntima y afectiva, individual y colectiva, le valga como recurso para el cambio de la conciencia social. Esta base religiosa se justifica cuando se implora la ayuda divina y se requiere de la imagen protectora más cercana, la Virgen de Guadalupe: “con el patrocinio declarado de la Madre Santa de Guadalupe, Numen Tutelar de este Imperio y Capitana Jurada de nuestras Legiones" (II, pág. 17).

El carácter irrespetuoso inserto en el discurso panfletario con el que se pretende incorporar a todos los individuos de una audiencia vinculada socioculturalmente a una lucha política concreta, se exhibe igualmente en el texto religioso. Para el Payo del Rosario supone un nuevo espacio en el que interpelar al pueblo, tradicionalmente comprometido con el aprendizaje de la doctrina cristiana a través de los catecismos.

Sus reiteradas manifestaciones anticlericales, públicamente aireadas a través de las imágenes y textos panfletarios ${ }^{16}$, lo definen como acérrimo enemigo de la religión católica. Sin embargo, ante esta actitud de rebeldía laicista, cabe la matización, continuamente expresada por su autor, de que su enfrentamiento va dirigido contra la autoridad eclesiástica y no reniega de Dios. Es la figura papal la más denostada en el texto, junto con la de los clérigos. Así, en el listado de los artículos de los coyotes, que pertenecen a Roma, se detalla:

El primero creer, que el papa es el dueño absoluto de todas las monarquías del mundo y que puede darles y quitarlas á su antojo, por mas que no encontremos ese poder en todo el nuevo testamento (8).

El tercero creer, que sin el pasaporte del obispo de Roma no podemos entrar al cielo ni ser cristianos, como si la fé y las virtudes estubieran estancadas en su palacio y la misericordia de Dios en la gavetitas de su bufete.

16 Helia Bonilla (2007: 131-133) describe las dos o tres imágenes que se asocian a este espíritu anticlerical de Villavicencio. Una primera, publicada en 1822, presenta la imagen de un seglar que expresa la divisa inquisitorial "Exurge Domine, judicam causam tuam" (Levántate Señor, y juzga tu causa), e intenta apuñalar, por la espalda, a un seglar y lanzarlo a la hoguera, en representación, al parecer, del propio Lizardi. La segunda imagen anticlerical, de 1829, va dedicada al obispo de Puebla, D. Antonio Joaquín Pérez Martínez, en la que aparecía como maronero en una cuerda para luego caer parado, por una proclama servil que había realizado. Una tercera, que no se ha conservado, y a la que hace referencia el propio autor, es una estampa en la que se ridiculiza nuevamente a la Inquisición. 
El quinto creer, que se puede despojar à los pueblos de sus libertades y uncirlos al carro de un tirano (9).

Entiende que solo ofende a Dios quien jura en su nombre y opta por "traerle por testigo de cosas falsas y mal hechas" (43), como es el caso del coyote. El anticlericalismo se asienta en la complicidad del poder eclesiástico con los intereses más conservadores, como aliado fiel en la defensa de sus consignas a cambio del mantenimiento de sus prerrogativas. A su vez, desde la Iglesia se establecía el grado de honradez y de compromiso social para el ejercicio de cualquier cargo en la comunidad y así se consigna en su primer mandamiento:

El primero, oir misa entera los domingos y fiestas de guardar, aunque no haya ganas, porque cumpliendo con este precepto se les tendrá por hombres de bien, los harán diputados, alcaldes, regidores (6).

Aborrece al clero porque consigue "minar el edificio de la libertad tras los parapetos del pulpito y confesionario" (8). Convence a los poderosos para "dejar el caudal a los hijos y a los frailes" (6), y perpetuar, de esta forma, el mantenimiento servil de "tanto canónigo holgazán" (7). Critica la hipocresía de todos ellos, "convertidos de pastores en Lobos" (9) para el pueblo, y se enfrenta al reiterado mensaje de vasallaje feudal con el régimen monárquico, porque "la religion nunca puede mandar a ningun hombre que sea esclavo de otro" (32). Separa, no obstante, aquellos frailes mexicanos que se alían con la causa revolucionaria, aun a costa de sus vidas, y acusa al poder monárquico de "haber asesinado injustamente a tanto sacerdote patriota en la insurreccion" (6), porque cree que "los sacerdotes que le son adictos podrán contrarrestar al clero mexicano, que lo aborrece" (11). Únicamente detesta a los que representan al "demonio en figura de hombre que son los malos frailes coyotes" (53), que encarna el segundo de los enemigos de la libertad: "el segundo son los frailes chaquetas, que son el mismo demonio amortajado" (15).

La hispanofobia, provocada por el sentimiento de odio a todo gobierno realista y al consecuente sometimiento colonial, se había asentado en la población novohispana, ávida de promesas liberales, y deseosa de la ruptura total con la metrópolis y con sus principios monárquicos. Si al principio se constata en Villavicencio una actitud de respeto por los españoles americanos, acorde con las ideas de su amigo Iturbide ${ }^{17}$, su posicionamiento se hace más

17 Villavicencio había criticado a quienes agitaban la consigna antiespañola desde una parte del movimiento iturbidista en los últimos momentos del imperio (Bonilla 2007: 134). 
extremista y la exigencia de su expulsión más contundente. El tono radical antiespañol de sus escritos responde a la polarización más jacobina en la defensa del cambio constitucional, asumida ahora en los círculos de la masonería yorquina frente a los postulados más conservadores de la escocesa.

Ya desde el inicio, se alude a la maldad del gobierno borbónico, empeñado en "oprimir á los americanos como enemigos malos" (1), del rey Fernando, "Por su crueldad, por su despotismo, por sus vicios y por la plenitud de poder que pretende sobre todos" (26), y de sus representantes en América, los denominados coyotes, "que sostienen la inicua dominación del tirano español" (7). Desmonta las tesis continuistas, vistas en las Cortes de Cádiz, que mantienen la lealtad al rey y su poder en las colonias de América. Para el Payo del Rosario, la cruz y la espada se conciertan en la conquista con resultados desastrosos para los americanos, "Porque con esta insignia venerable vino el conquistador Cortés á asesinar a millares de hombres, a saquear este suelo y a despojar a Moctehazoma de su imperio" (26-27). A pesar de que la presencia española en el México independiente era poco significativa numéricamente, algo más de 6500 personas, su importancia se basaba en la pertenencia a sectores de la elite comercial militar y política (Pani 2003: 357), por lo que se convierte en un pilar indispensable para el régimen colonial. Se trata del sector minoritario que acapara la riqueza y el bienestar del país, de ahí que se aviven los movimientos hispanófobos ${ }^{18}$ y se reclame que haya "diputados, hombres de bien y valientes que propongan su espulsion como perjudiciales a la seguridad pública" (19). Reniega de los españoles, por su tradicional y engañoso espíritu de hidalguización ${ }^{19}$, que, "contando la nobleza de su casa, aunque hayan sido cocheros ó verdugos" (5), desean un trato más acorde con este sentimiento: "P. Para que son necesarios los dones del espiritu español? R. Para que no nos traten en la America,

18 Partidario de una ley de expulsión de los españoles más severa y sin las excepciones contenidas en la emitida en 1827, participa en los sucesos del Motín de la Acordada, que provocará su promulgación, en 1829. Como había referido en un panfleto de 1824, El Hermano del Payo del Rosario, El hijito del Coyote que cuidaba a las gallinas, o sea suplemento al número primero de su Señor padre, editado en Puebla, pág. 4 (cita de Pani 2003: 361): "Nula es nuestra independencia / falsa nuestra libertad, / mientras tengan los coyotes / el palo, el mando y el pan".

19 De la soberbia tópica española también se hace eco en su escrito de Defensa que hizo el Payo del Rosario en la Sala del Crimen de esta capital ante el Tribunal de Jurados, de 1824, al traer a colación el dicho, ya comentado por el español Cadalso, de que "ha llegado á ser proverbio entre ellas decir que el inglés pide limosna llorando, el italiano cantando, y el español mandando" (pág. 9). No en vano, en este escrito religioso llama a los gobernantes cubanos enviados para la sofocación del movimiento revolucionario "mandarinos de la Habana" (17), con alusión al estatus que en las Indias Orientales tienen en la población china. 
de el tio Perico, el tio Joanico o el tio Chepe; sino de dones y muy dones y señorias" (61). Abomina de ellos porque viven "de lo que se roba en el comercio engañando a los bobos" (6), y por su falta de generosidad, "viendo el pago que se han sacado de haberlos admitido como a hermanos" (16).

A esta falta de moral cristiana en las instituciones civiles y eclesiásticas, que ocultan los defectos y perversidades cometidas con el poder del dinero, se refiere continuamente el Payo del Rosario, que recuerda determinados tópicos en contextos como el que sigue, "teniendo dinero ya se sabe que aunque seamos judios y tontos se nos tiene por cristianos y discretos" (49), y en los versos arromanzados con los que termina su alusión al pecado:

Porque hay de por medio empeños. / Por saber gratificar / Por decir una lisonja. / Por ser picaro el fiscal / Porque impone á los devotos / el ropaje episcopal: / Por el profundo respeto, / a un hábito monacal: / Por que no hay coyote malo / como tenga buen caudal: / Porque juren los iberos / de nuevo fidelidad. / Por ofrecer un buen cohecho. / Todo aquesto dicho y hecho / con tino y habilidad (23).

\section{BURLA Y SARCASMO EN LA CATEQUESIS POLÍTICA}

El Catecismo, publicado en México en 1827, continúa con el recurso a las parábolas tradicionales en sus panfletos, con los personajes centrales en la refriega política, los coyotes $^{20}$, identificados con los españoles, y las gallinas con los mexicanos. Consciente de la funcionalidad instructiva del texto doctrinal, nuestro escritor se sirve del registro alegórico para la denuncia pública de personajes reales, fácilmente reconocidos por los ciudadanos, y de sus responsabilidades políticas y sociales, expuestas ante la opinión pública que valora, de esta forma, el grado de injusticia en sus actitudes. Recoge toda la crítica mordaz expresada en los escritos y panfletos anteriores y recalca la complicidad del estamento eclesiástico con el poder establecido. A través de la burla continuada de los contenidos religiosos del catecismo tradicional, se lleva a cabo una denuncia de las ideas políticas conservadoras

20 Término que designaba en esta época al ‘criollo, hijo de europeo', aunque antes, como recoge Alvar (1987: 111), se utilizaba para referirse a otros cruces raciales: 'hijo de barcino y mulata', 'hijo de mestizo e india', 'hijo de chamizo y mestiza', 'cruce de indio y coyote', 'cruce de mulato y chamizo', todos en México. 
y una defensa combativa del espíritu revolucionario: "Todo fiel Iberiano está muy obligado de todo corazon con la santa inquisicion y el gobierno de un Bórbon, pues en el quieren vivir para mas oprimir á los americanos como enemigos malos" (1). Proclama la libertad de los individuos y advierte contra los peligros que la acechan: "Los enemigos de la libertad son tres. El primero es el mundo infestado de coyotes serviles; el segundo son los frailes chaquetas, que son el mismo demonio amortajado; y el tercero la carne que estos quieren devorar" (18), con alusión inequívoca a la comparación simbólica de gallinas y coyotes, que son los que "afilan el diente para comer gallinas" (23), y cuyo fin es "buscar en el último rincon de la tierra, gallinas que cazar" (28).

El mecanismo alegórico conlleva el símil como medio del cambio referencial con la intencionalidad política subyacente. Desde el inicio del catecismo, las metáforas y las comparaciones construyen el tipo de escrito panfletario, pleno de burla y de sarcasmo, con el que se imputan a los responsables políticos los hechos objeto de crítica. Así, todo fiel cristiano queda nombrado por Todo fiel Iberiano, la Santa Cruz, por la Inquisición, y Cristo, por el Borbón (1). Dios Padre se identifica con el rey Fernando VII, "santificado por los serviles y execrado por los hombres libres" (2), y los hijos borbonistas sustituyen a Jesucristo. La Madre de Dios, abogada y protectora de todos nosotros, queda sustituida por la ancestral Iberia, la de "d. Pelayo" (44), la "España de Castilla é Indias" $(19,36)$, que protagoniza la conquista criminal de Cortés $(11,16)$, la "fanática, legítima madre de los godos!" (4), que nos gobierna con el auxilio del "consejo de Indias fruto maldito de tu infernal política" (4). En lugar de titular los enemigos del alma se coloca el rótulo los enemigos de la libertad (15); con el espíritu del español se oculta el teológico Espíritu Santo $(18,19)$; se añade a la Salve filiación extraña y contraria a los americanos, Salve de España; para el Ave María se emplea el rótulo Ave América mía, intencionalmente patriótico, como se demuestra en la fe de erratas incluida al final del escrito, como nota de aclaración: "En la pág. 39 se dice declaracion del ave Maria, lease del ave America mia" (64).

Además de la identificación irreverente de elementos religiosos doctrinales con personajes y conceptos obviamente connotados de intencionalidad ideológica y política, en el escrito se señala, con sus denominaciones, a personas y hechos fácilmente reconocidos por el pueblo americano, como el del padre Arenas, repetido varias veces, los de Leonardo Bravo (12), José Iturrigaray, Morelos, Rayones, Matamoros, Salto, Guerrero, Iturbide (24), la insurrección de 1810 (29), el Plan de Iguala (2), "la tercer garantia" (63). Discute "el derecho de conquista (que es siempre el del ladron)" (10), derecho legalmente consolidado por la autoridad papal: "no cudiciarás las 
cosas agenas mas que la América, y eso porque nos la dió el papa Alejandro Sexto, como se lo puedes preguntar a un sr. Diputado de Puebla que con el mayor garbo ha citado en el congreso esta memorable autoridad" (5). Con los denuestos a la familia monárquica, busca la quiebra de su fundamento moral: "Fernando el bruto su hijo promogénito, señor nuestro que fue concebido por obra de d. Manuel Godoy y nació de la prostituta Luisa de Parma" (3). Tampoco escapa a su denuncia política la prensa de sus adversarios, especialmente la de los editores de $\operatorname{El~Sol}(5,45)$, complaciente ante las injusticias sociales, y a los que critica que "sigan corrompiendo la opinion con impunidad y desverguenza" (14), cuando se refieren a los "yorquinos, a los editores del correo y a todos los buenos patriotas" (5).

El Payo del Rosario se vale de todos los elementos, personajes e instituciones, que representan o sostienen el régimen monárquico y antiliberal de la metrópolis, utilizados ahora como bases referenciales de los propiamente religiosos, para desentrañar, mediante la alegoría continuada y el estilo burlesco, el código político del pueblo insurgente y la defensa de las ideas liberales ilustradas; todo con el objetivo de destruir el estado social de dominación material y espiritual de los individuos.

El imaginario popular lleva a la simbología política de ciertos animales, a los que tradicionalmente habían recurrido los panfletistas y la prensa más comprometida con los procesos revolucionarios. El águila y el león protagonizan el enfrentamiento entre América y España. Para los insurgentes americanos, los gachupines o españoles eran víboras, monstruos carnívoros, tigres, buitres, lobos, leones, leopardos, coyotes que no vivían de su trabajo sino de sangre y opresión ${ }^{21}$. Los calificativos más usados para denostar todo aquello que representara al poder peninsular muestran explícitamente esta caracterización zoomórfica. De esta manera aparece en La Salve de España, "vuelve a nosotros esos tus ojos de Lince" (4), se define la "monarquía feroz" (6), y se alude a los "Leones y castillos" (41). Se insiste en el consejo de que hay que apartarse de "vivir con esta clase de vichos" (19), por la poca humanidad de los españoles, que tratan a los mexicanos como a guajolotes, como a "pavos de corral" (20).

La concepción burlesca y sarcástica del Catecismo asegura la reiteración de tales procedimientos, con metáforas y comparaciones que convierten, como se dice textualmente, el objetivo didáctico de instrucción juvenil en puro divertimento jocoso. 
Así, en la exposición de los dones del Espíritu Santo, aquí español, se comenta el cambio social que se produce en los españoles al llegar al Nuevo Mundo: "El primero don, de sabiduría para llenar á la América de grumetes polisones y en pocos años volverlos gobernadores, alcaldes y empleados públicos" (18). En la oración de la Salve, se afirma: "el señor oro es contigo" (2), y para la comentada Santa Madre de Dios o América, la crítica xenófoba resulta manifiesta: "santa América mia madre de dos, del estrangero y el español" (3). Idéntico proceso se descubre en otras muchas citas, con interpretaciones sarcásticas fácilmente deducibles: "Creo en Cárlos IV rey poderoso criador de los disturbios y las guerras" (3), "amarás al oro sobre todas las cosas y a tu prójimo contra una esquina si es liberal" (4), "no hurtarás públicamente sino con disimulo" (5), "Paz sepulcral la que desean los coyotes para los mejicanos" (20), "coyotes limpios de corazon y de la bolsa" (22), etc.

\section{EL VOCABULARIO IDEOLÓGICO Y LENGUA COMÚN}

La realidad histórica social y sus nuevos planteamientos ideológicos generan un cambio en el lenguaje y provocan que los términos usados adquieran los contenidos semánticos de la política del momento ${ }^{22}$. El objetivo propagandístico, con su supuesta finalidad educativa de la juventud, del Catecismo político burlesco asegura la presencia de este campo léxico, con palabras del contexto ilustrado que denotan apreciaciones partidistas y connotaciones radicalmente ideologizadas. En esta época postindependentista, el vocabulario propio del movimiento iluminista y de la insurgencia americana resultaba habitual en los contextos políticos

22 Aunque este cambio ideológico es palpable en la sociedad, y así se reconoce ya en el Nuevo Vocabulario Filosófico-Democrático del jesuita Lorenzo Ignacio Thiulen, escrito en italiano en 1799 y traducido al español en 1813, "Es verdad que las voces son las mismas; pero también lo es que muchísimas de ellas, y de las de más importancia, no significan ya lo que antes significaban", también cabe insistir, como comenta este mismo autor, en el grado de desconocimiento que las nuevas acepciones supone para los ciudadanos: "comenzó todo el mundo á gritar pacto social, libertad, igualdad, derechos, sin saber ni entender lo que significaban estos vocablos" (Franco Figueroa, 2011: 3). Al estudio de esta parcela léxica, con evidentes motivaciones históricas y sociales, ha dedicado su investigación el profesor Álvarez de Miranda (2004), que recalca el fenómeno de la poligénesis temporal de términos, con referencia al incremento del vocabulario que se percibe en el Siglo de Las Luces. 
y sociales, difundidos por la prensa, cartillas y catecismos, y toda clase de libelos, panfletos e imágenes involucrados en su aceptación ${ }^{23}$.

Contra el mantenimiento del antiguo régimen y su concepción monárquica del gobierno de los pueblos, los individuos se inclinan por la reivindicación de sus derechos, con términos que completan el campo semántico del nuevo estado social que preconizan. La falta de saber y de cultura los convierte en "hombres serviles" (39), "infelices americanos" $(10,61)$, fácilmente engañados por los poderosos, ayudados por el estamento eclesiástico: "cuando les viene el mal pensamiento de destruir á los americanos que no quieren ser sus siervos, se agarran fuertemente à la religion y de este modo han solido alusinar al vulgo necio y devotamente preocupado" (27). Contraria a la voz luz, sinónima del saber y de la cultura, se manifiesta la confusión de alucinar y, en el mismo sentido, aparece el término preocupado ${ }^{24}$, ahora identificado como 'el hombre que no posee ilustración' (García Godoy, 1998: 96, 97), "hombres preocupados" (9). No interesa a los sectores conservadores la difusión de la cultura en el pueblo, "a quien siempre es menester conservar en su embrutecimiento" (34). Para los insurgentes, los remedios para la salvación de América se hallan en "La ilustración, el conocimiento de los derechos del hombre, y saber cuanto vale la independencia y la libertad" (54). No en vano sus opositores claman "maldita ilustración" (49), y se duelen de "la tristeza que nos dá del bien que ha resultado a la nacion mexicana, y prosperidad en que se haya con su independencia y libertad" (57). Las consignas políticas fragmentan la sociedad en los dos bandos opuestos según sus posiciones ideológicas. Unos son tachados de "rebeldes mexicanos" (36), masón (37), denunciados por conspirar (35) y por herejes (46); a otros se les achaca el seguir la "doctrina de Maquiavelo" (26), y practicar el despotismo (26). Se les acusa de abogar por la conservación de los conceptos feudales vasallo (35), que representa al individuo sin sus derechos fundamentales, contrario al término ciudadano (38), o de amo (25), y de consentir la "esclavitud española" (16), ratificada

23 Al léxico de la Aurora de Chile (1812-1813) y del Catecismo político cristiano de Amor de la Patria (1811) nos dedicamos en nuestros trabajos respectivos (Franco Figueroa 2010 y 2011).

24 La sensación metafórica de alucinar para describir el embaucamiento del pueblo como método despótico hablamos en el Catecismo político de Amor de la Patria, en 1811 (Franco Figueroa 2011: 8). De ella se hace eco también el Payo del Rosario en El gallo se halla durmiendo y los coyotes velando, de 1825: "para el fanatismo, luces" (9), "esta falta de luces, a merced de la cual, nos oprimieron, nunca pudo legitimar la usurpacion" (10). El $V F D$ recuerda el uso del término despreocupados en la ideología ilustrada y sus sinónimos "Filósofos, liberales-mazones, espíritus fuertes, despreocupados, ilustrados" (I, 45). 
en el sistema colonial, "esclavos o colonos" (52). Dentro de la Iglesia, como institución, la imputación más repetida para un sector del clero recae en su complicidad con los poderes realistas y más conservadores en América. Se les tilda con la adjetivación despectiva chaquetas ${ }^{25}$, "frailes chaquetas" (15), porque predican la contra revolución (50).

La identificación de los habitantes en el contexto colonial conlleva igualmente su diferenciación social y política. A la generalización del gentilicio americano para establecer una separación de los nacidos en ese continente frente a los residentes naturales de Europa, se suma ahora el ahondamiento en la exclusión racial que suponen la voz criollo (13), y los términos más despectivos con los que referirse a los españoles, como son godo, gachupín, chapetón y coyote. Frente a lo inculcado desde la Península, que considera que los habitantes de América son españoles, con la primera palabra citada se observa que a la acepción primitiva más general, de individuos nacidos en el Nuevo Mundo, sin referencia a la etnia, se añade el sentido más restrictivo impuesto en esta etapa revolucionaria, 'hijo de españoles nacido en América', con evidente connotación racial de 'blanco' frente a otras razas llegadas a la colonia hispana (García Godoy 1998: 166, 167). El desprecio de los liberales americanos por aquellos que representan la opresión metropolitana llega también a términos como $\operatorname{godo}^{26}(4,23)$, con acepción política que recuerda Marty Caballero, "Nombre con que se designa en Buenos Aires y alguna otra parte de la América meridional, á los españoles, y principalmente á los que han sostenido en aquellos paises los intereses de la antigua metrópoli”. El apelativo gachupín será el más empleado en la Nueva España insurgente frente al de chapetón que tiene un mayor uso en la zona peruana: "Responderá su nombre: chapetón godo ó gachupín" $(25)^{27}$. Los improperios más repetidos se dirigen al gachupín, abundantes, "infinito número que hay en la república de gachupines vivos capitulados, y no capitulados para tomar las armas contra la independencia" (14), y al coyote, representante de todos los males de América como constata en su definición expresa: "Cierto animal astuto, Zocarron, rapàz y sanguinario conque han simbolizado á los malos españoles que tienen

25 García Godoy (1998: 296) recoge esta acepción 'mejicano partidario de los españoles', creada, según las obras lexicográficas que consulta, en la Nueva España, y añade que antes de aplicarse a los criollos tránsfugas se utilizaba para designar a los españoles disidentes del gobierno del virrey Iturrigaray, en un contexto de 1812.

26 Con definición claramente partidista en la Aurora de Chile (Franco Figueroa 2010: 128): "voz usada en México a los enemigos de la libertad, subversores del gobierno" $(42,3)$.

27 Del Catecismo político de Amor de la Patria viene esta declaración, ahora reiterada por el Payo del Rosario (Franco Figueroa 2010: 14). 
sus mismas costumbres" (26). Ambos términos presentan derivaciones que inciden en su matiz social despectivo: gachupinesca (45), coyotezca (46, $60)$, coyotuna (60). Incluso se nombran los descendientes de los coyotes, sus coyotitos, y se componen palabras que incluyen el odio que producen junto con los individuos americanos que los siguen en sus ideales serviles y contrarrevolucionarios, los denominados gallinas $(23,28,41)$ : coyotitos (44), gallicoyote $(7,14,20,37,42)$. El mismo sentimiento de menosprecio por razón étnica lleva consigo la voz africano equiparable a la de godo, "africanos y godos" (49).

La soberanía recae en la voz patria (5), con sus derivados patriota, compatriota (26), conceptos que representan la nueva mentalidad ilustrada, y en la que los "buenos patriotas" $(5,21)$ hacen valer sus derechos y con la que se comprometen en su defensa y contribución para el bien común, para la construcción del concepto edificio social (56). A este campo semántico pertenece el término paisano $(5,17)$, como personas que pertenecen a la misma patria ${ }^{28}$, y la más repetida, nación, vinculada primero a América y luego más concretamente a México, nación mexicana $(23,35)$. No sorprende que en el Catecismo del Payo del Rosario, comprometido con su tierra mexicana, se produzca una reflexión de tono federalista, cercano a las ideas norteamericanas: "P. ¿Porqué hay tanta variedad de naciones en América, y se llaman por tantos nombres como de México, Colombia, Chile, Rio de la Plata, etc. / R. No es sino una sola nacion americana" (40). Es consecuente cuando escribe "ciudadanos de la república mexicana" (38) y repite el gentilicio mejicanos / megicanos $(20,60)$, como forma de identificación nacional de sus paisano ${ }^{29}$ frente al iberiano (1). Recoge también la tradicional referencia diatópica de América septentrional (39), con la que todos, especialmente los independentistas, designaban a la América mexicana o los territorios conocidos e integrantes de la Nueva España ${ }^{30}$.

En el léxico de las estructuras políticas, tenemos muchos de estos términos con sus derivados que se definen en el nuevo orden político. Se habla de las cortes españolas (3), congreso (5), gabinete de Madrid (8), del término clave constitucionales (36), sistema federal (58), de las repúblicas

\footnotetext{
28 En España, el uso de esta voz se halla asociado, como sinónimo, a la del término patricio (García Godoy 1998: 143).

29 García Godoy (1998: 161), con cita de Álvaro González acerca de la proclama del cura Hidalgo, en 1810, recuerda que el gentilicio mejicanos no existía en esos momentos, de ahí que se dirija a su auditorio con la voz americanos.

30 De esta sinonimia habla García Godoy (1998: 160). Cabe recordar, igualmente, que la denominación de América Meridional obedece al interés por separar estas provincias de las colonias inglesas del norte (DPI, 91).
} 
de América (10), del republicano (44), o del neologismo trigarante (24) alusivo al Plan de Iguala, con valoraciones distintas según coincidan o se opongan a los criterios ideológicos liberales. No en vano se ironiza con el deseo ferviente de todo coyote o español: "Gozo espiritual el que tuvieran si vieran quemados a todos los liberales" (20).

Fuera del vocabulario más específico, el escrito del Payo del Rosario revela la variedad y heterogeneidad lingüística del texto, con su español aclimatado al solar americano, y más concretamente a la realidad mexicana. La aparición de construcciones habidas en el español de otros tiempos nos acerca a estilos más tradicionales y a la formalidad de los registros escriturarios. Es lo que se observa en el uso pronominal de nos $(2,37)$ por nosotros, o el tratamiento de vos $(24,29)$, ya desprestigiado en esta región americana. Aún se ironiza cuando se dice "hablarnos de su merced para infundirnos mas orgullo" (12). Se localizan construcciones gramaticales que muestran los rasgos preferenciales del dialecto americano, muchos de ellos tenidos más tarde por arcaicos en la Península. Al empleo de afuera (53), allende, aquende (46), añadimos los usos tradicionales del futuro de subjuntivo, viniere (60), el popular arcaísmo disque (7), o la mayor presencia del subjuntivo en - $r a$, "si se acabára en el mundo, resucitará con nosotros" (45), "el que tuvieran si vieran" (20). Aún sigue la forma apocopada de los numerales, "la tercer garantia" (63); la ausencia de nexo, "así parece debia ser" (48); de la preposición $a$ en el objeto de persona, "se les da para mantener los canónigos" (48), y en regímenes, "ir cantar responsos" (32); o del artículo ante el relativo, "todo esto de que estamos nosotros convencidos" (32). Sí encontramos el leísmo de persona, bastante extendido por las hablas americanas y peninsulares: "la tranquilidad de que le habeis privado" (34), "¿quien le cumple?" (44), ofrecernosle (51), "les llaman de hereges" (46), "llamarle de padre" (35), con función predicativa de la preposición de.

El vocabulario más popular y de uso familiar tiene su hueco con voces como amistar (44), aparentar 'presentase, aparecerse' (28), arrancada 'mala, arruinada', (5), pintiparar 'comparar' (34), pieza 'habitación, cuarto' (12), etc. No obstante, no faltan ejemplos de palabras de reciente documentación: pantalones de brin (12), con documentación de la 'tela de lona' a finales del s. XVIII, y con el registro de la prenda en 1800, aunque la Academia no había incluido hasta 1843 (DCECH), y al que Álvarez de Miranda (2004: 1053 ) incluye en el grupo de voces francesas que penetran en nuestra lengua en el s. XVIII; chaquetón, "chaquetones de marina" (12), que la Academia no recoge hasta 1884 (DCECH).

Son abundantes los términos de adscripción americana, y muchos de ellos identificados como mexicanismos. Así, se registran americanismos generales como arranquera 'falta de dinero, pobreza' (47), que el DRAE adscribe 
a Canarias y a Cuba, bravo 'indómitos, salvajes' (50), drogas 'deudas' (63), frijol (47), gallego ${ }^{31}$ 'inculto' (13), 'sirviente' (19), usual en América Meridional (Morínigo), largar 'lanzar, tirar' (42), overo 'animal salpicado de manchas' (51), aquí referido metafóricamente a la persona afectada del mal gálico o venéreo, volteandotele (5), referido a la nación, con el significado americano de 'derribar, tumbar', etc. Del ámbito indigenista podemos citar las voces nahuas cacomiscle (cacomizcle) 'especie de comadreja' (25), guajolote (20), quimiles 'lío de ropas' (19). Entre los dialectalismos mexicanos tenemos pulque (47), de etimología discutida, y los registrados por la Academia amolarse 'frustrarse' (54), caravana 'reverencia' (42), escamocha 'sobras de comida' (6-7), o el apelativo étnico loba (8), 'zamba, hija de indio y negra, o al contrario'.

No escapan a la tendencia dialectal la diptongación popular mexicana en arcabuciados (62), ni los rasgos fonéticos deducibles de los trueques gráficos, aun contando con la cautela que un texto impreso conlleva. Así, además de neutralizaciones reiteradas en sesto (9), o espulsión (19), abundan los fonetismos seseantes como sentralistas (45), sercenar (17), chispaso (9), crusifijo (27), inosente (61), machetaso (51), polisón ${ }^{32}$ (18), tropieso (53), pescueso (50), unsion (51), sona (40), o el indigenismo nahua sopilote (13), con casos de trueques ceceantes: arcenales (44), fucilado (30), pretenciones (31). La indistinción de las palatales central y lateral explican el trueque en "nos hallan hecho los megicanos" (60).

Su comentada identificación con los habitantes del pueblo, peones y hombres sin oficio que provienen de la clase más baja, justifican que su discurso político quede impregnado de elementos fraseológicos y giros más coloquiales. En esta parcela podemos citar las siguientes frases y locuciones: "donde grita el cochino robado allí se le suelta el mecate" (10), "estacar la salea en unas visperas cicilianas" (13) 33 , "alborotar el cotarro" (45), "están

31 La imposición de la lengua como fuente de poder, sobre todo entre la población indígena y entre los criollos incultos, se convierte igualmente en objeto de crítica y denuncia por su efecto de disgregación social: "y á veces enseñarnos a pronunciar el castellano y mas si eramos gallegos" (13).

32 El marinerismo polizón se incluía en el vocabulario despectivo de los liberales americanos, con el significado de 'parásito, ocioso', que ya Terreros recogía: "Polizones ó llovidos, llaman en América á los Españoles que van allá de España sin licencia del Rei, ni su Consejo, sobre que hai un tit. en la Recopilación de Indias: de aquí se toma Polizón por lo mismo que parásito, y ocioso" (Franco Figueroa 2011: 14).

33 Frase mexicana con el sentido de 'morir' $(D R A E)$, a la que se añade otra con alusión a la terrible matanza que ejecutaron los sicilianos con los franceses en vísperas de la Pascua de Resurrección, en 1822. 
tan verdes como decia la zorra" (44), "hacer el vervi gracia" (19), "pegar un petardo" 'engañar' (24), "pensando en la musarañas" (47), "salirse con la suya" (16), "á lo calladito" (21), "a mas no poder" (2), "bajo cuerda" (18), "debajo de cuerda" (21), "como todo hijo de vecino" (31), "gente de buen diente" "muy buenos comedores' (47), "por la friolera" (56), etc.

\section{EPÍLOGO}

La saturación de imágenes y de textos religiosos en los panfletos y en la prensa postindependentista se explica por la convicción generalizada sobre la eficacia que este formato posee para el cambio de mentalidad en las comunidades más populares. El Catecismo político burlesco, como literatura panfletaria de combate, representa un juego de imágenes alegóricas que constituyen el discurso más eficaz para la propaganda política insurgente. Es un texto polémico por su arquitectura religiosa, pero popular y divulgativo, por las expresiones satíricas y burlescas que amortiguan la violencia verbal de sus denuncias sociales. Por su estilo crítico y mordaz, unido a su carácter más simbólico y sarcástico, el espíritu irreverente que conlleva el uso de los elementos doctrinales de un catecismo queda oculto por los personajes y hechos que los sustituyen, ajenos a la verdad teológica original del texto catequético e identificados por sus acciones contrarias a la moral cristiana.

Este escrito, dialógico y constreñido por su estructura religiosa, además de su primaria función ideológica, constituye un cuadro representativo del lenguaje habitual del Payo del Rosario en la totalidad de su obra. Emplea la diversidad léxica para establecer un vocabulario político que muestre su intencionalidad propagandística, con voces que acaparan las nuevas acepciones del ámbito insurgente y liberal, y para construir una forma de habla habitual y comprensible para sus paisanos, que exprese el pretendido cambio de conciencia social. La reiteración de los términos difundidos ya por el movimiento revolucionario de los primeros años del s. XIX no es óbice para valorar su talento literario, comprometido con su uso tajante e inflexible en la defensa de la causa liberal mexicana. Su Catecismo, que imita la estructura y replantea sus contenidos catequéticos por los ideales políticos, sigue, entonces, el modelo de tantas cartillas y catecismos publicados desde los inicios de la insurgencia e independencia americanas; sin embargo, los mecanismos de la persuasión y del convencimiento para la difusión y para la asunción de las nuevas ideas políticas logran convertirlo, por su sentido burlesco, en un juego, en una diversión como el autor reivindica, para 
crear un lenguaje emotivo con el que los posibles lectores, o sus oyentes, comulguen con los ideales ilustrados que él se afana por contagiar: libertad, igualdad e independencia.

\section{REFERENCIAS BIBLIOGRÁFICAS}

Alvar, Manuel. 1978. Léxico del mestizaje en Hispanoamérica. Madrid: Ediciones Cultura Hispánica-Instituto de Cooperación Iberoamericana.

Álvarez de Miranda, Pedro. 2004. El léxico español, desde el siglo XVIII hasta hoy. En Rafael Cano Aguilar (coord.). Historia de la lengua española. Barcelona: Ariel, págs. 1037-1064.

Bonilla, Helia. 2007. El Payo del Rosario: imágenes anticlericales y antihispánicas en la panfletografía postindependentista. Millars: Espai i Historia, 30, págs. 123-137.

Bustos, Miguel. 1827. Catecismo civil o de instrucción elemental de los derechos, obligaciones y gobiernos en que debe estar impuesto el hombre libre, formado para la enseñanza pública de las escuelas del Estado de Guanajuato. México: Imprenta de Mariano Arévalo, ed. facsímil de la Universidad Nacional Autónoma de México (Libros antiguos, catecismos y cartillas); [en línea] http://www.derechosdelhombre.unam.mx/libros.htm.

Constitución Politica de la Monarquia Española promulgada en Cádiz a 19 de marzo de 1812, Cádiz, Imprenta Real, edición facsímil, vol. III, estudios de Alberto Ramos et al, vols. I-II, Sevilla, Universidad de Cádiz, Ayuntamiento de Cádiz, Casino Gaditano y Fundación El Monte, 2000.

Corominas, Joan y José Antonio Pascual. 1980-1991. Diccionario crítico etimológico castellano e hispánico. Madrid: Gredos. (DCECH).

El Despertador Americano. 1810-1811. Consulta en la web de la Biblioteca Virtual Miguel de Cervantes (2011), texto digitalizado del original de la Biblioteca Virtual Antorcha; [en línea] http://www.antorcha.net/index/biblioteca.html.

Fernández de Córdoba, Joaquín. 1961. Pablo de Villavicencio (El Payo del Rosario). Artículos periodísticos de doctrina y combate. V. III. Culiacán: Ediciones Culturales del Estado de Sinaloa.

Fernández Sebastián, Javier (dir.). 2009. Diccionario político y social del mundo iberoamericano. La era de las revoluciones. 1750-1850. Madrid: Fundación Carolina, Sociedad Estatal de Conmemoraciones Culturales, Centro de Estudios Políticos y Constitucionales. $(D P I)$.

Franco Figueroa, Mariano. 2010. Independencia y su expresión léxica en la Aurora de Chile. Boletín de Filología de la Universidad de Chile, XLV, 1: 127-157.

2011. Lengua y libertad: el léxico del Catecismo político cristiano de José Amor de la Patria (1811). Cuadernos de Ilustración y Romanticismo, 17 (2011), págs. 1-18; [en línea] consulta en http://revistas.uca.es/index.php/cir.

García Godoy, Ma Teresa (1998), Las Cortes de Cádiz y América. El primer vocabulario liberal español y mejicano (1810-1814), Sevilla, Servicio de Publicaciones de la Diputación de Sevilla.

Lleal, Coloma. 1982. El panfleto político: forma y estructura. Anuario de Filología 8: 211-225.

Marty Caballero, D. E. 1871. Diccionario de la lengua castellana, I, II. Madrid: Manuel Rodríguez, Editor.

Morínigo, Marcos. 1985. Diccionario de americanismos. Barcelona: Muchnik Editores. 
OCAMPO LóPEZ, JAVIER. 1988: Los catecismos politicos en la independencia de Hispanoamérica. De la monarquía a la república. Tunja, Universidad Pedagógica y Tecnológica de Colombia.

Olea, Héctor. 1987. Panfletografía de El Payo del Rosario: (Semblanza de Pablo Villavicencio). Culiacán: Universidad Autónoma de Sinaloa.

PANI, ERIKA. 2003. De coyotes y gallinas: hispanidad, identidad nacional y comunidad política durante la expulsión de españoles. Revista de Indias, LXIII, 228, págs. 355-374.

Real Academia Española. 2001. Diccionario de la lengua española. Madrid: Espasa Calpe; [en línea], consulta en http://www.rae.es/rae.html. (DRAE, Academia).

RoJas, Rafael. 1997. Una maldición silenciada. El panfleto político en el México independiente. Historia Mexicana, XLVII, I, págs. 35-67.

2003. El arquetipo del panfletista político. La escritura de la Independencia: el surgimiento de la opinión pública en México. México: Taurus y Centro de Investigación y Docencia Económicas, págs. 168-195.

Sagredo Baeza, Rafael. 2009. De la Colonia a la República. Los catecismos políticos americanos, 1811-1827. Madrid: Fundación Mapfre y Ediciones Doce Calles.

Sánchez Hita, Beatriz. 2003. Cartillas políticas y catecismos constitucionales en el Cádiz de las Cortes: un género viejo para la creación de una nueva sociedad, Revista de Literatura, LXV, 130: 541-574; [en línea] consulta en http://revistadeliteratura.revistas.csic.es.

Sotés ElizAlde, M. Ángeles. 2009. Los catecismos políticos e instrucción política y moral de los ciudadanos (s. XVIII y XIX) en Francia y España. Educación XXI, 12, págs. 201-218.

Thiulen, LoRenzo Ignacio. 1813. Nuevo vocabulario filosófico-democrático, indispensable para los que deseen entender la nueva lengua revolucionaria. Escrito en italiano, y traducido al español. Sevilla: ed. facsímil de la reimpresión hecha en Barcelona, de Editorial Máxtor, Valladolid, 2006 (VFD).

VÁzquez Semadeni, María E. 2009. Masonería, papeles públicos y cultura política en el primer México independiente. 1821-1828. Historia Moderna y Contemporánea de México, 38, págs. 35-83.

Villavicencio, Pablo de. 1824. Defensa que hizo el Payo del Rosario en la Sala del Crimen de esta capital ante el Tribunal de Jurados: Ratificando lo que dijo en su papel del Coyote. México: Biblioteca Digital Hispánica de la Biblioteca Nacional de España, signatura H-A 23980; [en línea] http://bibliotecadigitalhispanica.bne.es.

1825. El gallo se halla durmiendo y los coyotes velando. México: Biblioteca Digital Hispánica de la Biblioteca Nacional de España, signatura H-A 24328; [en línea] http://bibliotecadigitalhispanica.bne.es.

1827. Catecismo político burlesco de los coyotes, para instrucción de la juventud, de El Payo del Rosario. México: Imprenta de la calle de Ortega, ed. facsímil de la Universidad Nacional Autónoma de México; [en línea] http://www.derechosdelhombre. unam.mx/libros.htm.

Zúñiga y Ontíveros, Mariano José De (ed.). 1820. Cartilla ó Catecismo del ciudadano constitucional. México. Biblioteca Digital Hispánica de la Biblioteca Nacional de España, signatura H-A 23711; [en línea] http://bibliotecadigitalhispanica.bne.es. 